\title{
Turkish Foreign Policy Towards Balkans and Serbia Under Davutoğlu Administration ${ }^{*}$
}

\author{
Davutoğlu Döneminde Balkanlarda ve Sırbistan'da Türk Dış Politikası
}

\author{
Sanja AREŽINA ${ }^{* *}$
}

\begin{abstract}
Developments in geopolitics of the Eurasia emphasize the presence and the role of Turkey. Its position has substantially changed since the 1970s and 1980s and its influence has become far more visible. As multidimensionality becomes the characteristic of its foreign policy, Turkey is becoming more active on the Eurasian geopolitical scene, trying to establish itself as (macro) regional power in the process of creating a multipolar world order. Serbia comes into focus of Turkey's foreign policy as a key state in the Balkans that represents, in addition to the Middle East and the Caucasus, its primary sphere of influence and a bridge to the West in which Turkey carries out visible political, economic and cultural impact. This paper deals with modes of Turkey's cooperation with Balkan states, primarily Serbia, and with the influence that public opinion has on their bilateral relations.
\end{abstract}

Keywords: Turkey, Foreign policy, Serbia, Balkans, Public perception.

Öz

Avrasya jeopolitiğindeki güncel gelişmeler Türkiye'nin varlığını ve rolünü vurgulamaktadır. 1970'lerden ve 1980’lerden bu yana Türkiye’nin konumu önemli ölçüde değişmiştir ve etkisi çok daha görünür hale gelmiştir. Türk diş politikasında çok boyutluluğun temel bir özellik haline gelmesiyle birlikte, Türkiye, Avrasya jeopolitik sahnesinde çok daha aktif hale gelmekte ve çok kutuplu bir dünya düzeni yaratılma sürecinde kendisini (makro) bölgesel güç olarak konumlandırmaya çalışmaktadır. Sırbistan, Ortadoğu ve Kafkasyaya ilaveten, Türkiyenin başlıca kültürel, ekonomik ve siyasi nüfuz alanı olan ve Batı ile köprü vazifesi gören Balkanlarda anahtar bir devlet olarak Türk dış politikasının odağı haline gelmektedir. Bu çalışmada, Türkiye’nin başta Sırbistan olmak üzere Balkan ülkeleriyle olan işbirliği biçimleri ve ikili ilişkilerde kamuoyunun sahip olduğu etki ele alınmaktadır.

Anahtar Kelimeler: Türkiye, Dış politika, Sırbistan, Balkanlar, Kamuoyu algısı.

* Bu makale Marmara BAPKO projesi kapsamında SOS-L-080715-0354 numaralı L tipi proje desteği ile hazırlanmıștır.

** Dr Sanja Arežina is a member of the Management Board of Belgrade Strategic Dialogue Foundation sanja_arezina@yahoo.com 


\section{Introduction}

The geopolitical position, economic and cultural power made Turkey one of the key Mediterranean countries, which plays an important role in the region and beyond. As the only legitimate successor to the Ottoman Empire, whose shores are washed by the Mediterranean, Aegean, Marmara and Black seas, and which controls the Bosphorus and the Dardanelles, Turkey has serious political potential, and its central Eurasian geopolitical placement gives it much greater opportunities than most states have in the area and makes it the relevant factor in all developments that spill over from the Middle East to the Balkans and further, to the Catholic-Protestant areas of Europe (Novi standard, 2010).

While the world has for decades cynically viewed Turkey as 'a man of strong arm, on an empty stomach, of small brain and weak heart', the beginning of the 21st century is marked by its rapid economic rise (Politika, 2012). It is a member of the G-20, NATO, the Organization for Security and Co-operation, Organization of the Islamic Conference, the Organization for Economic Cooperation and Development, the Organization for Black Sea Economic Cooperation and the D-8. Its essential feature is the large demographic potential (population of 75 million). Although the natality is in slight decline compared to the previous decade, it is still considerably higher compared to the European average. According to estimates of the United Nations (UN) in 2050 Turkey will have population of around 95 million.

Turkey's economy is characterized by explosive growth, which far exceeds the European average. In the 2002-2014 period the average economic growth stood at $4.7 \%$. Turkey is ranked 16th globally in purchasing power (Invest in Turkey, 2016). By gross national income per capita, it is wealthier than the poorest member of the European Union (EU), such as Latvia, Romania and Bulgaria. The economic crisis had largely bypassed Turkey and due to that it has become an attractive economic and political partner, who is pacing to reach the level of the average income of the European Union. Turkey is an important military power (its armed forces are 7th largest in the world) with one of the best equipped armies in NATO. Also, it is a de facto nuclear power because it hosts important NATO nuclear capabilities (Balcer, 2011, 1).

Developments in geopolitics of the Eurasia emphasize the presence and the role of Turkey. At the beginning of the $21^{\text {st }}$ century, its position has substantially changed since the 1970 s and 1980s and its influence has become far more visible. Yesterday's 'sick man from Bosphorus' has recovered and became a respected global player (DW, 2011). Turkey is no longer a 'western gate keeper' or 'geo-strategic pivot' to stabilize the Black Sea region, but 'geostrategic player' which will play an increasingly important role in its entire wider neighborhood. Therefore its foreign policy is increasingly being marked by multi-dimensionality which aims to promote international and regional cooperation (Brzezinski, 2001, 48).

One of the primary spheres of interest and a bridge to the West in which Turkey exerts political, economic and cultural influence is the Balkans. The three most important aims of the Turkish diplomatic initiative under Davutoğlu administration in the Balkans were to strengthen the good 
relations with traditional Balkan partners, to open up towards countries with which there are problematic relations and to play the role of mediator and guide multilateral initiatives in order to promote regional stability (Davutoglu, 2008, 79-84). Accordingly, Turkey was trying to foster good relations with all the countries of the Balkans, especially with Serbia as a key country in this area.

This paper consists of five parts. The first part explains the importance of Turkey in international relations as well as changes that have recently taken place in its foreign policy. The second part discusses the changes that have taken place in Turkey's foreign policy under Davudoğlu administration. The third part explains the practical application of Turkey's foreign policy in the Balkans. The fourth section analyzes how the public perception affects the cooperation of two countries. In the last and final part lists the concluding observations.

\section{Turkish Foreign Policy in the beginning of the 2 I st Century}

Like many other countries today, Turkey is coping with the internal soul-searching, consolidation and quest for new perspectives of its own domestic and foreign policy. Its foreign policy has long been characterised by the absence of any serious intention to project its power. What was propagated was peace at home and peace abroad, a calm, friendly and stable environment, establishment of good relations with neighbors, non-interference in the internal affairs of other states and the abandonment of any pretense towards regional dominance (Tanasković, 2010).

The new assertive foreign policy on a global scale and, within it, regional policy towards the Western Balkans, can be linked to the period from 2002 and onwards, during which the country has been ruled by the Justice and Development Party (AKP). The main creator of Turkish foreign policy in this approach is Ahmet Davutoğlu, former Minister of foreign affairs and Prime Minister, who was able to translate his academic ideas into concrete foreign policy doctrine and practice (Ajzenhamer, Trapara, 2013). In his 2001 book Strategic Depth, as in many other papers, lectures and speeches as official of the Turkish state, Davutoğlu has clearly and precisely laid out the basic principles and objectives of the foreign policy of Turkey, referring to the geographical position and historical tradition of the country.

In terms of geographical location, Davutoğlu sees Turkey as a central country in the AfroAsian mass that has a space for and also an imperative to use active foreign policy to exerts its influence on neighboring regions and thus reach the status of a global power. This imperative has been made possible since the end of the Cold War, because Turkey did not feel bound by the logic of the division of the superpowers' spheres of influence, in which it played the role of the frontier state of the West towards the East, which gave the possibility of creation of its own sphere of influence (Strategic Depth, Davutoglu, 2008, 78). Besides geography, Turkey is looking at its history too, which gives credence to the idea of central authority in the region, because the population of the surrounding states had immigrated to Turkey after the breakup of the Ottoman Empire (Davutoglu, 2008, 79). Today it exerts special political, economic and military influence towards the countries in its wider neighborhood that once belonged to the 
Ottoman Empire. Such a foreign policy orientation was called 'neo-Ottomanism' (Yavuz, 2008, 9-41, Laçiner, Bal, 2011, 167, Tanasković, 2010). It generally looks at Turkey as a 'heart' of Eurasia rather than a 'bridge' to it; its natural center which will play a key role in resolving the political and economic issues over a wide area 'from the Adriatic Sea to Central Asia'. In other words, Turkey can not be assumed as a peripheral country whose political role is limited to be a 'bridge' between civilizations, but will undertake an active foreign policy and become a center of political decision-making and 'State lighthouse', i.e. the central government, which has a strong influence on its civilization zone (Avijucki, 2009, 25). According to Davutoğlu, in order to achieve this, Turkey needs to build a new identity, compatible with its new ambitious role in a broad region of Eurasia (Petrović, 2011, 6).

The Turkey's strategic vision 2023 policy paper from 2009 was a step towards achieving this goal, created for the occasion of the centennial of the Republic of Turkey. It predicts that some significant progress must be made in the following 14 years by focusing on the vision and objectives, excluding interference and achieving full coordination among all state institutions. In this way, by unlocking certain internal tensions and through significant social and systemic reforms, Turkey wants to achieve social cohesion internally and move from conflict to cooperation externally. The idea was that Turkey could be a prestigious actor on the international level only if it is powerful enough to accomplish its goals.

Five principles that underlie Turkish foreign policy are: the balance between security and democracy (show Turkey as a democratic country that fully comply with Western values), the policy of 'zero problems with neighbors' policy that reduces the problems plaguing bilateral relations and limit Turkey's room for maneuver at regional and global levels (Tanasković, 2010), proactive and preventive peace diplomacy aimed at fostering security and high-level political dialogue, economic integration, interdependence and multicultural coexistence, multidimensionality with which Turkey wants to supplement its NATO role by building relationships with other influential players such as Russia, and 'rhythmic diplomacy' which means an increased role for Turkey in international and multilateral agreements (Davutoglu, 2009). In fulfilling these foreign policy principles, Turkey wants to develop itself into a global actor that respects human rights and develops a high standard of living.

\section{Turkey's Activity in the Balkans}

As part of Davudoğlu's strategy of 'return' to the Balkans, Turkey is gradually but steadily trying to increase its influence in the countries within this region. This continuity is not disturbed even by the fact that for the last few years its foreign policy's maximum attention has been deployed in the Middle East, where Turkey is still trying to 'tame' the consequences of the Arab Spring. The focus of Turkey's Balkan policy are two countries with substantial Muslim minority, and those that do not have significant percentage of Muslim population (like Croatia, where Dogus Holding has invested in ports in Šibenik and Zadar, as well as in hotels in Dubrovnik, Šibenik, Makarska 
and Zadar). Turkey returns to this region gradually and tactically, primarily through economic cooperation and expansion of various forms of so-called 'soft' power (trade, foreign investment, education investment, construction, turism, development aid, etc, Balcer, 2011, 1, Nye, 2004, 5, 6, 60). An important factor in its return to the Balkans is the fact that international engagement after the wars of 1990s has somewhat stalled, and a large number of unresolved issues (functionality of post-Dayton Bosnia and Herzegovina, the problem of Kosovo and Metohija) gave an excuse to Turkey for its attempts for the 'correction' of the current situation.

In Bosnia and Herzegovina, the Turkish presence is most visible and most intense. Turkey is a member of the Peace Implementation Council (where it represents the Organization of the Islamic Conference, Preporod, 1992, 10), the institution that oversees the application of the provisions of the Dayton Agreement in Bosnia and Herzegovina (Ruma, 2010, 135). However, it stands as de facto protector of Bosniaks claiming that Dayton cannot fully ensure their safety and wellbeing. Through Intensive investment and attempts to keep afloat the stalled Bosnian economy, Turkey creates the image of Bosnia's largest patron and the 'second home' for Bosniaks. In recent years, Turkey made several major investments: Kastamonu Entegere - Natron-Hayat in Maglaj, Soda Sanayii AS - Sisecam Soda Lukavac in Lukavac and TC Ziraat Bankasi - Turkish Ziraat Bank Bosnia in Sarajevo. Turkish Airlines has purchased 49\% of Bosnian flag carrier in 2008. Turkey's financial institutions (TaksaBank, Istanbul Stock Exchange and the Central Registry of Securities, Turkey) was carried out by the recapitalization of the Sarajevo Stock Exchange (SASE) and now owns 15\% of its capital (BH-News, 2011). For the critical group of products in the food industry, Turkey has opened quotas for imports from Bosnia and Herzegovina. Turkey's Exim Bank plans to invest in infrastructure, roads and power grid of Bosnia and Herzegovina. A section of the highway around Sarajevo was completed by Turkish company Cangiz Insaat (Al Jazeera, 2014). Also planned is the opening of numerous schools and universities where classes are not only attended by the Bosniak pupils and students, but also record a large influx of Turkish students for which their government provides favorable scholarships.

Turkey pays special attention to Serbia, seeing it as a key strategic country for securing and strengthening its influence in the Balkans. As a result, the summit in Istanbul in April 2010 and the Istanbul Declaration that followed have been characterized as very important rapprochement step between Serbia and Turkey (Ruma, 2010, 136). The view that relations with Belgrade should be conditional to the situation in Bosnia and Herzegovina has been dropped, meaning that there is no expectation any more that Serbia should pressure Republic of Srpska to be more accomodating towards Sarajevo. A new approach to Serbia has a different position: 'Serbia does not have full control over the Bosnian Serbs, to the extent that Bosnian Serbs have somewhat replaced their discourse of joining Serbia with a self-confident reference to pure independence, especially after Kosovo has declared its own independence. This problem complicates further Serbian efforts to prevent the independence of Kosovo (Ruma, 2010, 136). While being aware that Belgrade has neither simple nor direct control over Bosnian Serbs, Turkey had in recent years tried to use intensified cooperation with Serbia to further isolate and seclude Republic of Srpska. In this light, we should look at pursued trilateral cooperation between Turkey, Serbia and 
Bosnia and Herzegovina as well as Turkey's assertive moves to improve mutual relations of these countries, which Banja Luka saw as one of the mechanisms by which Turkey was trying to favor the Bosniaks (Blic, 2011). Namely, in Republika Srpska the 'Trilateral' Sarajevo-Belgrade-Ankara dynamics was seen as a Turkish attempt to win the regional support to strengthen the Bosniak positions in complicated Bosnian situation (Slobodna Evropa, 2010)

After three summits - in Istanbul 2010, Karadjordjevo 2011 and Ankara 2013, eight meetings of foreign ministers, two declarations, a number of agreements including the Free Trade Agreement, the statement of Recep Tayyip Erdogan that 'Turkey is Kosovo, Kosovo is Turkey' has led the president of Serbia Tomislav Nikolić to freeze Serbia's participation in trilateral talks (Politika, 2013). Two years later, the foreign ministers have met and discussed the future of these meetings agreeing only that greater economic cooperation was in the immediate interest of all parties. Therefore the ministers of trade begun to meet once a year within a new mechanism Trilateral committee for economic cooperation of Serbia, Turkey and Bosnia and Herzegovina. In this regard, increased inflow of Turkish investments in Serbia indicates closer rapprochement between Belgrade and Ankara (RTS, 2015). Turkish Halk Bank bought the majority share of Čačanska banka on March 20, 2015, cargo flights between Belgrade and Istanbul have started, Turkey's low-coster Pegasus Airlines opened scheduled flights from Belgrade to Istanbul (Sabiha Gökçen International Airport) on February 1, 2013. Textile factories were opened in Leskovac and Krupanj, Teklas Automotive opened its plant in Vladičin Han and Aster Tekstil (textile) opened its factories in Niš, reconstruction was started on EI Čegar (metals) factories in Niš and a school in Novi Pazar, along with several bridges (Novi Pazar is the center of Muslim minority in Serbia). After the 2014 Serbia floods, Turkey has donated significant relief to Serbia and has opened Turkish Cultural Center in Belgrade (Blic, 2015, Večernje novosti, 2016, Blic, 2016, Srbijadanas, 2016).

Volume of trade between Turkey and countries of former Yugoslavia and Albania makes only 0.9 percent of Turkey's total foreign trade, which is half of the trade with Romania, for example (Blic, 2015). Telecommunication are the most developed area of cooperation with Albania, where Turkish capital is present in two operators - Albtelecom (telecommunications) and Eaglemobil (internet), as well as in the largest state bank $B K T$. Since the declaration of independence of Macedonia, Turkey has provided strong support to this country, especially in its dispute with Greece over the country's name. Turkey's capital is present at two airports - Skopje and Ohrid. It is also present in real estate development, in 40 floors high-rise residential building in Skopje, in Department of Ophthalmology, with a branch of Halkbank, several Ramstore supermarkets owned by Koch, as well as dairy products factory Sutash (Slobodna Evropa, 2015). Turkey has improved its relations with its main local rival Greece, diminishing existing tensions and supplementing them with successful economic cooperation. In Montenegro, the Turkish company Tosyali Holding has invested in Nikšić steelworks, Global Ports Holding as a container and general cargo terminal in the Port of Bar. In early April 2015, Ziraat Bank has obtained the license from Central Bank of Montenegro and has rented one-third of an office building in downtown Podgorica (Balkans Aljazeera, 2014). Turkish construction company Gintas has invested 50 million euros, 
in partnership with the City of Podgorica which provided land and communal services, in the construction of the shopping mall, one of the largest retail outlets in Montenegro - Mall of Montenegro, which houses a modern closed green market and shopping center with shops, restaurants, cafes, various entertainment, and Ramada hotel (Slobodna Evropa, 2015).

In Kosovo and Metohija, whose independence is strongly supported (which is an additional barrier to the improvement of Serbian-Turkish relations), Turkey also plays a visible role through a combination of economic and infrastructural arrangements and new educational institutions, with the intensive presence of numerous NGOs. The Turkish-French consortium Limak-Aeroport de Lyon has won the contract to manage the International Airport Adem Jashari in Pristina in May 2010, for a period of 20 years. As part of the agreement the Turkish company has pledged to invest ( 80 million euros) in airport infrastructure. In 2012 Calik Holding and Limak became the owners of local company for distribution and supply of electricity - KEDS. The US-Turkish consortium Bechtel-Enka has worked on the construction of the highway Vrmnica - Pristina Merdare, which connects Kosovo and Metohija with Albania. The same consortium is the winner of the tender for the construction of the highway Prishtina - Elez Han (General Janković), which connects Kosovo and Metohija to Macedonia (Blic, 2015).

Turkey is strongly engaged not only in real estate and infrastructure construction but also in building specific areas of civil society in Kosovo and Metohija. It is estimated that the Turks in Kosovo and Metohija are a minority of some 30000, ie. 1.5 percent of the total population and are mostly settled in the area around Prizren and Kosovska Mitrovica. Therefore, Turkey is very active in assisting its 'diaspora' through a large number of Turkish NGOs. Coordinating role of TIKA Turkish International Cooperation and Coordination (Türk İşirliği ve Kalkınma Ajansi), which in recent years has a branched network of 'facilitators' and maintained constant communication with local NGOs (about 20 organizations, mainly in Pristina and Prizren). Educational center Bejza, as well as Turkish Cultural Center 'Kemal Ataturk' could be added in this basket. Through the 'Great Student Project' (Büyük Öğrenci Projesi), which was initiated in the early 1990s by Turgut Ozal, Turkey has become an educational meeting place for hundreds of Albanian students on scholarships, as well as several thousand of those who are studying at their own expense. According to official data of the Turkish Ministry of Education, its universities have 5 times more students from Kosovo and Metohija on scholarships then from Bosnia and Herzegovina. There is no doubt that the majority of these students will return to Kosovo and Metohija and that the contacts established during their stay will have a paramount importance for mutual relations. By educating future diplomats, politicians, military officers, with opening of Turkish schools, Turkey forms the basis for an even stronger presence in the region for which it has a backing of the United States. Turkish National Television (TRT) has programs in Turkish, Azerbaijani, Kyrgyz, Kazakh, Uzbek and Turkmen language supplanted by programs in Bosnian, Albanian and Serbian languages (Zaman, 2010). In Kosovo and Metohija some dozen newspapers are published in Turkish, some of which are the most popular Tan, Darlik Jeni Donem, Sesimiz, etc. In addition, four radio stations - 'Kosovo Radio,' 'Kent FM' and Prizren's 'New period radio' and 'Mehmetcik' (radio of the Turkish KFOR in Prizren) regularly broadcast programs in Turkish. 
For a few hours a week, the programs are broadcast in Turkish and in particular through Kosovo TV channels.

Bearing in mind that the stability of the Balkans is in the interest of Turkey, its political engagement in the region went hand in hand with the military one. Turkey's military and police units have been given an important role in post-conflict missions and peacekeeping deployment in Bosnia and Herzegovina, Kosovo and Metohija and Macedonia. With the rise of political and economic influence, Turkey has stepped up military cooperation on bilateral levels with armies and defense ministries in the region. Military cooperation mimics the intensity of political relations and ranges from training programs to the modernization of military infrastructure (eg. Vlore in Albania, which still houses Turkish troops, naval school and reconstruction of military airport in Kučova) and assistance in military equipment. Turkey has also improved its military cooperation with Serbia and Montenegro. It participated with 10 million US dollars in the reconstruction of dualuse Morava-Lađevci, a military airport near Kraljevo, which was officially opened in October 2011. Cooperation with Montenegro is based primarily on the activities within the framework of the NATO Membership Action Plan and cooperation between navies of the two countries (Petrović and Reljić, 2011). Just as in the Middle East, Turkey has initiated visa relaxation schemes with the Balkans, namely with Albania, Macedonia, Serbia, Montenegro, Kosovo, Bosnia and Herzegovina, and after that together with the United States showed an interest in boosting traffic infrastructure in Serbia (in Raška), Kosovo and Metohija, Bosnia and Herzegovina and Albania, and their connection into singular transportation region (Marković, 2011, 63-54).

\section{The Influence of Public Perception on Serbian-Turkish Relations}

Most of the Balkan people built their identity in past centuries in a negative way towards the Ottoman Empire. Such a distance was kept up to date due to historical memory, prejudice and usually incomplete information provided by media. Many stereotypes and suspicions that arise in public feed the impression that Turkey's foreign policy is based more on ideology than on national interests, and that the main foreign policy objectives are the improvement of Turkey's relations with the Islamic world and the motive of the expansion across the Balkans through political, economic and cultural power. One of the reasons could be found in Davutoglu's speech to the members of the Justice and Development Party in November 2009, when he stated that his country was indeed implementing the policy of neo-Ottomanism. 'There is a heritage left by the Ottoman Empire. We are called 'neo-Ottomans'. Yes, we are 'neo-Ottomans'. We are obliged to deal with the neighbor countries and we even get to Africa. Great powers are watching it in bewilderment' (News.As, 2009). A contributing factor surely is the assertiveness which is becoming one of the characteristics of Turkish foreign policy in the 21st century.

Upon focusing on the suggestions of its academic and professional community interested in foreign policy rhetoric and its effects in the Balkans, Turkey began to gradually distance itself from recalling its Ottoman roots, realizing that it usually provokes accusations of neo-Ottomanism. 
Davutoğlu's clumsy rhetoric about the revival of the 'Ottoman success story in the Balkans' has at the very least provoked Serbian nationalists and has proved very detrimental to Turkey's ambitions to become a regional mediator. Frankly, the Ottoman reference might be useful when it comes to the Turkish / Muslim population in the Balkans, but it is self-destructive when it comes to others....' (Ruma, 2010,139). That such suggestions have been taken into account we could see August 2011 when, during a visit to Kosovo and Metohija and Bosnia and Herzegovina, Ahmet Davutoğlu criticized the use of the term 'neo-Ottomanism' as a term describing the foreign policy of Turkey, and dampened the glorification of the Ottoman heritage (otherwise heavily used during his stay in Sarajevo in the fall of 2009) into a narrative of 'common past' between Turkey and other nations in this region (Hurriyet daily news, 2011). By carefully planning its appearance and dosing its presence and the way it spreads its influence, Turkey has shown that it is capable of greater flexibility towards Balkans, and of adjusting itself to emerging situations.

However, Turkish support for the independence of Kosovo through the Organization of the Islamic Conference, has had strained relations with Serbia. Another example was the Turkish interference in the conflict between two Islamic communities in Serbia - the Islamic Community in Serbia and the Islamic Community of Serbia. Turkey's initiative for 'reconciliation' and reunification of the feuding Islamic communities in 2011 caused a huge controversy in the Serbian public. In fact, Turkey's proposed solution went at the expense of the Islamic Community of Serbia, because it meant its effective elimination under the authority of the Islamic Community of Bosnia and Herzegovina, which would de facto abolish its independence. This solution was far from acceptable, because it was meeting only the demands of rival Islamic Community in Serbia, since Islamic Community of Bosnia and Herzegovina is largely seen as its spiritual and administrative center (Raković, 2012). This made Turkey's mediation in this case seen as extremely biased and openly supportive of one side in the dispute. However, we also must bear in mind that Turkey's involvement in this failed settlement that further divided the Islamic communities in Serbia should not be seen as some wanton interference in the internal affairs of Serbia (although the media had created such a picture). This 'intervention' was in large part the result of internal turmoil in the Serbian political scene, which, due to electoral calculations and the fear of the then-ruling coalition of the votes from Sandžak (a region with significant Muslim population), due to a possible political rapprochement of then-opposition leader Tomislav Nikolić and Mufti Muamer Zukorlić, has opened space for Turkish interference and even more than that - it created vacuum for Turkey to fill it. In fact, it appears that the then Serbian Government (or more precisely its certain parts) sought to gain from Turkish intervention which Turkish side accepted, eagerly trying to exploit the situation in order to strengthen its particular influence among the local Muslims and build its image of a successful mediator. In this situation, Turkey acted less on a prepared plan and more on a window of opportunity and inertia. Altogether, one can say that Turkey's mediation did not lead to the reconciliation of these two communities and that the problem still persists.

Erdogan's statement that 'Kosovo is Turkey, Turkey is Kosovo' in Prizren in October 2013 was a sufficient reason for the President of the Republic of Serbia Tomislav Nikolić to freeze its 
participation in the trilateral talks that started with the Istanbul declaration. The public have had the impression that the statement of Turkish Prime Minister was used as an excuse to end the meetings at the highest level. Similar statements were issued in 2016 as well, i.e. during the opening ceremony for the Ferhat-Pasha Mosque in Banja Luka (demolished in 1993), when exPrime Minister Davutoglu said that the Turks 'were here, are here now and will be here forever' (Blic, 2016).

A Gallup survey shows that less than 15 percent of Serbian citizens see Turkey as a friendly state (DW, 2012). This was mainly augmented by few political issues that continue to burden bilateral relations between the two countries, as well as a potential closer economic cooperation. Nevertheless, the two countries are trying to establish more harmonious relations. According to former Prime Minister Davutoğlu, 'in some ways, even the best of friends can have different opinions' (RTV, 2009). Therefore, the Turkish attention in relations with Belgrade has focused on the things that connect the two countries, rather than those that separate them. Issues of Turkey's one-sided approach to Yugoslav conflict and to the bombing of Serbia, in the opinion of some of the Turkish politicians should be left in the past. In the center-stage should be, the many centuries of common history, cultural closeness, and a somewhat different perception of the Ottoman past. Accordingly, Turkey reinvents itself as a friend and a regional stabilizing factor for Serbia and the Balkans, with the intention of benevolent political mediation and its influence in this area (Hurriyet daily news, 2009).

If we leave aside occasional provocative statements of Turkey's officials, we can say that the charges of neo-Ottomanism are largely caused by Turkey's assertive policies in the Balkans, that actually only reflects the increase in its international standing and economic boom of the last decade. It is clear that as a 16th world economy it is trying to further strengthen its export-oriented economy. Balkan has been playing a very important role because it lays on the main road to the Western market, and thus represents could present a leading trade partner for Turkey. Although more than 1 million Turks live in the Balkan countries, and some 10-15 million people with Balkan roots live in Turkey, they can constitute a powerful 'natural Balkan lobby' composed of associations, foundations, journalists, academics, parliamentarians, ministers and diplomats, it is usually the economic motives that, in fact, connect Turkey to the Balkans and Serbia specifically.

\section{Conclusion}

With the strengthening of the economy under the rule of Justice and Development Party since 2002, Turkish foreign policy has transformed itself from the reluctance to project power into a more assertive stance, and from one-dimensional (prioritising relations with NATO states) to multidimensional (expanding relations with Russian Federation, PR China and Eurasian countries), with the aim to develop the 'global actor' role who will be able to quickly adapt to new conditions and circumstances (Tanasković, 2010). 
In accordance with the 'strategic depth' ideas of Ahmet Davutoğlu, one of the major regions in which Turkey has wanted to expand its influence has been the South East Europe, and the Balkans within it, being seen as the 'gateway to Europe' due to its geographical role between Turkey and Central and Western Europe. A number of statements by senior Turkish officials that peace and stability among Balkan countries have been and remain very important for the security of Turkey as the Balkan country itself mostly speak in favor of it. High rates of economic growth, as well as various other forms of expansion of soft power such as the construction of investment structures, promotion of Turkish TV series and opening Turkish radio and TV stations in the region, help the growth of its influence. Thanks to its role as a locomotive of regional development and cooperation, Turkey has an opportunity to become more actively involved in solving problems that has long burdened the region and dragged its economy down. Therefore, it appears that the Turkish strategy under Davutoğlu administration has been to create partnerships with each country individually based on several different levels: political, economic, security, cultural, etc. On the other hand, it suits the Balkan states to have other strong alternative economic partner other then the EU, bearing in mind that most of them need additional capital inflows and investment for which the EU does not suffice.

Serbia for Turkey represents a key country of the Balkans with which it wants to maintain productive relations. Although many international and regional challenges are affecting them, those two countries seem to cooperate at a satisfactory level. The attitude of top officials is such that the two countries should ignore the differences that exist and to base relations solely on topics of positive mutual interest. A progress has been visible for the past few years as a result. Cooperation is focused exclusively on strengthening the political dialogue, regional cooperation as a component of the stabilization and development of the Balkans, as well as the promotion of economic cooperation. Although the statements of senior Turkish officials in connection with Kosovo, as well as the attitudes of Serbian wider public opinion, led to a temporary coolingoff period, thanks to efforts by the Serbian side cooperation resumed in April 2015 when the Protocol on inter-parliamentary cooperation was signed. A positive trend can be expected in the future. Therefore, the recommendation to politicians is that in accordance with national interests and pragmatic approach, further efforts be made to open up new opportunities for cooperation, especially in the economic field, and to do utmost to avoid relations based on ideology. 


\section{References}

Aljazeera. (2014) "BiH dobila novih 20 kilometara autoputa" [BiH got 20km of New Highways], 7. October, http://balkans.aljazeera.net/vijesti/bih-dobila-novih-20-kilometara-autoputa, accessed on 22.04.2016.

Avijucki, V. (2009) Kontinentalne geopolitike [Continental Geopolitics]. Beograd: Clio.

Ajzenhamer, V., V. Trapara. (2013) Turska politika prema Srbiji i Zapadnom Balkanu u kontekstu aktuelnih medunarodnih i regionalnih trendova, [Turkey's Policies towards Serbia and the Western Balkans in the Context of Current Internationaland Regional Trends], Beograd: Institut za međunarodnu politiku i privredu.

Balcer, A. (2011) Turska i zapadni Balkan pogled iz Poljske [Turkey and Western Balkans view from Poland], Beograd: ISAC, http://www.isac-fund.org/download/Turkey-and-the-Western-Balkans-srp.pdf, accessed on 27.02.2016.

Balkans Aljazeera. (2014) „Balkan i Turska - strategijska alijansa“ [Balkans and Turkish - Strategic Aliance], 10 August, http://balkans.aljazeera.net/vijesti/balkan-i-turska-strategijska-alijansa, accessed on 28.02.2016.

BH-News. (2011) "Slijedi nov val investitora iz Turske u BiH" [A new wave of investors from Turkey], 16 July, http://www.bh-news.com/ba/vijest/13255/slijedi_nov_val_investitora_iz_turske_u_bih.html, accessed on 23.02.2016.

Blic. (2011) "Dodik: U Karađorđevu se nije desilo ništa spektakularno" [It has not happened nothing spectacular in Karadjordjevo], 26 April, http://www.blic.rs/vesti/politika/250503/Dodik_U_ Karadjordjevu_se_nije_desilo_nista_spektakularno, accessed on 23.02.2016.

Blic. (2015) "Ljajić: Turska želi da ulaže, Srbija da bude kreativnija” [Ljajić: Turkey wants to invest, Serbia should be more creative], 26 March 2015, http://www.blic.rs/Vesti/Ekonomija/545760/LjajicTurska-zeli-da-ulaze-Srbija-da-bude-kreativnija, accessed on 26.02.2016.

Blic. (2016) "Obnavljanje džamije, Davutoglu na otvaranju Ferhadije: Turci su bili ovde, sada su i biće zauvek" [Mosque Restoration, Davutoglu at the Opening of Ferhadija: Turks were here, are here and will be here forever], 7. May, http://www.blic.rs/vesti/drustvo/obnavljanje-dzamije-davutoglu-naotvaranju-ferhadije-turci-su-bili-ovde-sada-su-i/mk4nv21, accessed on 22.05.2016.

Blic. (2016) "Vučić svečano otvorio fabriku turskog investitora u Vladičinom Hanu" [Vučić has Opened the Factory of Turkish Investor in Vladičin Han], 7. April, http://www.blic.rs/vesti/ekonomija/vucicsvecano-otvorio-fabriku-turskog-investitora-u-vladicinom-hanu/r4gd3yz, accessed on 22.04.2016.

Brzezinski, Z. (2001) Velika šahovska tabla [Big Chess Table]. Podgorica: CID.

Davutoğlu, A. (2009) Principles of Turkish Foreign Policy, Washington: SETA Foundation's Washington D.C. Branch, http://arsiv.setav.org/ups/dosya/14808.pdf, accessed on 27.02.2016.

Davutoglu, A. (2008) “Turkish Foreigh Policy Vision: An Assesment of 2007”, Insight Turkey, Vol. 10, No. 1. DW. (2011) „Bolesnik na Bosforu je odavno ozdravio“ [The Sick Man of Bosphorus Has Healed], 21. September, http://www.dw.com/bs/bolesnik-na-bosforu-je-odavno-ozdravio/a-15404219, accessed on 22.03.2016.

DW. (2012) „Ciljevi Turske na Balkanu“ [Turkey’s Goals in the Balkans], 22. May, http://www.dw.com/sr/ ciljevi-turske-na-balkanu/a-15966772, accessed on 22.03.2016.

Hurriyet Daily News. (2009) „Balkan Tension Must be Prevented, Says FM”, 24 July, www.hurriyetdailynews. com/n.php?n=balkan-tension-must-be-preventedsays-fm, accessed on 27.02.2016. 
Hurriyet daily news. (2009) “Turkish FM rejects 'neo-Ottoman 'label”, 28 August, http://www. hurriyetdailynews.com/default.aspx?pageid $=438 \& \mathrm{n}=$ turkish-fm-rejects-8216neo-ottoman 8217 label-2011-08-28, accessed on 23.02.2016.

Invest in Turkey. (2016) "Economic outlook", http://www.invest.gov.tr/en-us/turkey/factsandfigures/pages/ economy.aspx, accessed on 25.03.2016.

Laçiner, S., İ. Bal. (2011) USAK yearbook of international politics and law, Vol. 4, USAK: International Strategic Research Organization.

Marković, M. B. (2011) „Preko prošlosti u budućnost: povratak Turske na prostor bivše Jugoslavije“ [Over the past to the future: the return of Turkey in the former Yugoslavia], Politeia 2, http://fpnbl.org/ casopis/politeia_2.pdf, accessed on 27.02.2016.

News.As. (2009) 'Turkish foreign minister: We are neo-Ottomans', 24 November, http://news.az/articles/ turkey/3216, accessed on 25.03.2016.

Novi standard. (2010) “Da li je moguća antiamerička osovina Moskva-Ankara-Rim?” [Is it possible antiAmerican axis Moskow-Ankara-Rome?], 15 September, http://www.standard.rs/da-li-je-mogucaantiamericka-osovina-moskva-ankara-rim.html, accessed on 27.02.2016.

Nye, J. S. Jr. (2004) Soft Power: The Means to Success in World Politics, New York: PublicAffairs.

Petrović, Ž. N. (2011) Turkey's new approach to the Western Balkans, Belgrade: ISAC.

Petrović, Ž., D. Reljić. (2011) Republika ili sila na zapadnom Balkanu - nova politika i stari odnosi Turske na zapadnom Balkanu [Republic or power in the Western Balkans - the new policy and the old relationships of Turkey in the Western Balkans], Beograd: ISAC.

Politika. (2012) "Balkan ne sme da bude zatočenik prošlosti” [Balkans cannot be the prisoner of the past], 16 May, http://www.politika.rs/sr/clanak/219014/Балкан-не-сме-да-буде-заточеник-прошлости\#!, accessed on 22.03.2016.

Politika. (2013) „Kosovo je Turska, Turska je Kosovo“ [Kosovo is Turkey, Turkey is Kosovo], 7. November, http://www.politika.rs/sr/clanak/275125/Sta-da-se-radi/Kosovo-je-Turska-Turska-je-Kosovo, accessed on 22.03.2016.

Preporod. (1992) "Islamske informativne novine" [Islamic informative newspaper], Sarajevo, 15 February.

Raković, A. (2012) “Turska inicijativa i Islamska zajednica” [Turkish initiative and the Islamic Community], Politika, Beograd, 29 January, http://www.politika.rs/rubrike/ostali-komentari/Turska-inicijativa-iIslamska-zajednica.lt.html, accessed on 23.02.2016.

RTS, (2015) "Srpsko-turski odnosi, ekonomija u senci politike" [Serbian-turkish relations, economy in the shadow of politics], 24 June, http://www.rts.rs/page/stories/sr/story/9/Politika/1958537/Srpsko-tur ski+odnosi,+ekonomija+u+senci+politike.html, accessed on 25.02.2016.

RTV. (2009) “Turskoj agenciji TIKA omogućene aktivnosti u Srbiji” [Turkey’s TIKA Agency is Allowed to Operate in Serbia], 23. July, http://rtv.rs/sr_lat/politika/turskoj-agenciji-tika-omogucene-aktivnostiu-srbiji_139173.html, accessed on 22.03.2016.

Ruma, I. (2010) "Turkish Foreign Policy towards the Balkans: New Activism, Neo-Ottomanism or/so what?", Turkish policy qaterly, Vol. 9, No. 4.

Slobodna Evropa. (2015) „Nedovoljno iskorišćen potencijal turskih investicija“ [Underutilized potential of turkish investment], 30 May, http://www.slobodnaevropa.org/content/nedovoljno-iskoristenpotencijal-turskih-investicija/27044638.html, accessed on 29.02.2016.

Slobodna Evropa. (2010) "RS negoduje zbog Istanbulske deklaracije” [RS is against on Istanbul Declaration], 26 April, http://www.slobodnaevropa.org/content/istanbulska_deklaracija_reakcije/2025010.html, accessed on 23.02.2016. 
Slobodna Evropa. (2015) „Turska značajno investira u Makedoniju“ [Turkey significantly invest in Macedonia], 30 May, http://www.slobodnaevropa.org/content/turska-znacajno-investira-umakedoniju/27044615.html, accessed on 27.02.2016.

Srbija Danas. (2016) "Vučić u Nišu: "Mučio” sam turske investitore do tri ujutru - Biće još fabrika!" [Vučić in Niš: I 'tormented' Turkish investors until 3AM - There will be more Factories], 16. April, http:// www.srbijadanas.com/clanak/vucic-u-nisu-obisao-pocetak-radova-na-rekonstrukciji-fabrikeaster-tekstil-16-04-2016, accessed on 22.04.2016.

Tanasković, D. (2010) “Turska na putu neoosmanizma” [Turkey on the Neo.Ottomanism way], Politika, 11 March, http://www.politika.rs/rubrike/Svet/Turska-na-putu-neoosmanizma.lt.html, accessed on 27.02.2016.

Tanasković, D. (2010) Neooosmanizam: doktrina i spoljnopolitička praksa [Neo-Ottomanism, doctrine and foreign policy practice], Beograd: Službeni glasnik, Službeni glasnik Republike Srpske.

Večernje novosti “Turski Aster tekstil u Nišu otvorio fabriku”, 19 October, http://www.novosti.rs/vesti/ naslovna/ekonomija/aktuelno.239.html:630766-Turski-Aster-tekstil-u-Nisu-otvorio-fabriku, accessed on 22.10.2016.

Yavuz, H. (2008) Turkish identity and foreign policy in flux: the rise of neo-ottomanism, Critique: Critical middle eastern studie, Vol. 2, 99.

Zaman, „TRT Avaz, Arnavutça ve Boşnakça Yayına Başladı”, http://zaman.com.tr/haber. do?haberno=1016653\&title=trt-avaz-arnavutca-ve-bosnakcayayina-Basladi, $\quad$ accessed $\quad$ on 27.02.2016. 